\title{
Tristemma hirtum and Five Other Cameroonian Edible Plants with Weak or No Antibacterial Effects Modulate the Activities of Antibiotics against Gram-Negative Multidrug-Resistant Phenotypes
}

\author{
Gaëlle S. Nguenang, Armelle T. Mbaveng (D), Aimé G. Fankam, Hermione T. Manekeng, \\ Paul Nayim, Brice E. N. Wamba, and Victor Kuete $(\mathbb{D}$ \\ Department of Biochemistry, Faculty of Science, University of Dschang, Dschang, Cameroon \\ Correspondence should be addressed to Victor Kuete; kuetevictor@yahoo.fr
}

Received 17 December 2017; Revised 10 January 2018; Accepted 19 February 2018; Published 22 March 2018

Academic Editor: Carlos Henrique Gomes Martins

Copyright ( 2018 Gaëlle S. Nguenang et al. This is an open access article distributed under the Creative Commons Attribution License, which permits unrestricted use, distribution, and reproduction in any medium, provided the original work is properly cited.

\begin{abstract}
In order to contribute to the fight against infectious diseases, the in vitro antibacterial activity and the antibiotic-potentiating effects of Tristemma hirtum and five other Cameroonian edible plants have been evaluated against Gram-negative multidrug-resistant (MDR) phenotypes. The microdilution method was used to evaluate the bacterial susceptibility of the extracts and their combination to common antibiotics. The phytochemical screening of the extracts was carried out according to standard methods. Phytochemical analysis of the extracts revealed the presence of alkaloids, triterpenes, steroids, and polyphenols, including flavonoids in most of the tested extracts. The entire tested extracts showed moderate $(512 \mu \mathrm{g} / \mathrm{mL} \leq \mathrm{MIC} \leq 2048 \mu \mathrm{g} / \mathrm{mL})$ to weak (MIC > $2048 \mu \mathrm{g} / \mathrm{mL}$ ) antibacterial activities against the tested bacteria. Furthermore, extracts of leaf of Tristemma hirtum and pericarps of Raphia hookeri (at their MIC/2 and MIC/4) strongly potentiated the activities of all antibiotics used in the study, especially those of chloramphenicol (CHL), ciprofloxacin (CIP), kanamycin (KAN), and tetracycline (TET) against 70\% (7/10) to 100\% (10/10) of the tested MDR bacteria, with the modulating factors ranging from 2 to 128 . The results of this study suggest that extracts from leaves of Tristemma hirtum and pericarps of Raphia hookeri can be sources of plant-derived products with antibiotic modifying activity.
\end{abstract}

\section{Introduction}

During the last decade, the number of multidrug-resistant (MDR) pathogenic bacteria has dramatically increased all over the world [1-3]. The burden of MDR Gram-negative bacteria infections is particularly concerning because such bacteria are demonstrating resistance to nearly all currently licensed antibiotics $[2,4]$. As a consequence, inadequate empirical antibacterial therapy of severe infections caused by MDR Enterobacteriaceae as well as Pseudomonas aeruginosa and Acinetobacter baumannii has been associated with increased morbidity and mortality $[5,6]$. In this alarming scenario, the discovery of novel drugs that could provide clinical efficacy against MDR Gram-negative pathogens remains one of the keys to successfully overcome the tide of resistance $[1,4]$. Targeting MDR systems as efflux in antibiotic resistant pathogens seems to be one of the most important existing strategies $[4,7]$. For example, the drug combination ceftolozane-tazobactam has shown in vitro activity against selected MDR Gram-negative pathogens, including $P$. aeruginosa [8]. This combination is effective due to the ability of ceftolozane to evade multiple resistance mechanisms including efflux pumps, reduced uptake through porin channels, and modification of penicillin-binding proteins [9]. In the same goal, many other studies have been done and some are ongoing. Plants constitute an undeniable source for the discovery of new antibacterials acting directly as bacterial growth inhibitors or as antibiotic modulators [1012]. Previous works showed that edible plants have excellent antibacterial properties and could also act as antibiotic modulators [13-18]. In the continuous contribution to the fight against infections due to MDR bacteria, this study was 
aimed to investigate the in vitro antibacterial activity as well as the antibiotic modulating activities of leaves of Tristemma hirtum and five other Cameroonian edible plants against selected Gram-negative MDR phenotypes.

\section{Methods}

2.1. Plant Material and Extraction. Six edible plants were collected in Bapa $\left(5^{\circ} 16^{\prime} 0^{\prime \prime}\right.$ north, $10^{\circ} 20^{\prime} 0^{\prime \prime}$ east) and Dschang $\left(5^{\circ} 27^{\prime} 0^{\prime \prime}\right.$ north, $10^{\circ} 4^{\prime} 0^{\prime \prime}$ east), two localities in the West Region of Cameroon. Samples collected were leaves of Aframomum letestuanum Gagnep. (Zingiberaceae) and Tristemma hirtum P. Beauv. (Melastomataceae), leaves and stem of Aframomum alboviolaceum (Ridl.) K.Schum. (Zingiberaceae), Pericarps of Cucurbita pepo Linn. (Cucurbitaceae) and Raphia hookeri Mann \& Wendl. (Arecaceae), and the stem of Physalis peruviana L. (Solanaceae). The identification of the plants was done at the National Herbarium in Yaoundé (Cameroon), where the voucher specimens were conserved under the registration numbers (Table 1). The dried and powdered material $(100 \mathrm{~g})$ of each plant was macerated in $300 \mathrm{~mL}$ of methanol at room temperature for $48 \mathrm{~h}$ and then filtered using Whatman filter paper number 1 . The filtrate obtained was concentrated using a rotary evaporator under reduced pressure to obtain the crude methanol extract, which was kept at $4^{\circ} \mathrm{C}$ until further use.

2.2. Chemicals. Six reference antibiotics (RA) purchased from Sigma-Aldrich (Saint-Quentin-Fallavier, France) were tested: ceftriaxone (CEF), chloramphenicol (CHL), ciprofloxacin (CIP), erythromycin (ERY), kanamycin (KAN), and tetracycline (TET); $p$-iodonitrotetrazolium chloride (INT) (Sigma-Aldrich) was used as bacterial growth revelator; dimethylsulfoxide (DMSO) was used to dissolve the plant extracts.

2.3. Bacteria, Culture Media, and Growth Conditions. The twenty strains of Gram-negative bacteria tested in this study were MDR isolates (laboratory collection) and reference strains (American Type Culture Collection) of Escherichia coli (ATCC8739, AG100A, AG100ATet, AG102, MC4100, and W3110), Enterobacter aerogenes (ATCC13048, CM64, EA27, EA289, and EA294), Klebsiella pneumoniae (ATCC11296, KP55, KP63, and K24), Pseudomonas aeruginosa (PA01 and PA124), and Providencia stuartii (NEA16, PS2636, and PS299645). The clinical strains were the laboratory collection from UMR-MD1, University of Marseille, France. The bacterial features are reported in Table S1 (see supplementary materials). The microorganisms were cultured overnight on Mueller-Hinton Agar (MHA) $24 \mathrm{~h}$ prior to any assay. The Mueller-Hinton Broth (MHB) was used as liquid culture medium for susceptibility tests.

2.4. Preliminary Phytochemical Screening. Potential classes of potential antibacterial phytochemicals such as alkaloids (Dragendorff's and Mayer's tests), terpenoids: sterols (Salkowski's test), saponins (foam test) and triterpenes (Liebermann-Burchard test), and phenolics: anthraquinones (Borntrager's test), flavonoids (aluminum chloride test), polyphenols (ferric chloride test), and tannins (gelatin test) (Table 2) were investigated according to the described phytochemical methods $[19,20]$.

2.5. Microbial Susceptibility Testing. The minimal inhibitory concentration (MIC) and minimum bactericidal concentration (MBC) determinations on bacteria were performed using the rapid INT colorimetric assay [21] with some modifications as previously described $[16,22]$. Samples were dissolved in DMSO/MHB. The final concentration of DMSO was lower than $2.5 \%$. The 2 -fold dilutions of samples were made in 96-well microplates and the tested bacterial concentration was $1.5 \times 10^{6}$ colony forming units $(\mathrm{CFU}) / \mathrm{mL}$. The microplates were incubated at $37^{\circ} \mathrm{C}$ for $18 \mathrm{~h}$. All assays were in triplicate and were repeated thrice. Wells containing $\mathrm{MHB}$, $100 \mu \mathrm{L}$ of inoculum, and DMSO to a final concentration of $2.5 \%$ served as negative control. Extracts and CHL were tested in the concentration ranges of $16-2048 \mu \mathrm{g} / \mathrm{mL}$ and $2-256 \mu \mathrm{g} / \mathrm{mL}$, respectively. The MIC of each sample was detected after $18 \mathrm{~h}$ incubation at $37^{\circ} \mathrm{C}$, following addition $(40 \mu \mathrm{L})$ of $0.2 \mathrm{mg} / \mathrm{mL}$ of INT and incubation at $37^{\circ} \mathrm{C}$ for 30 minutes as the lowest sample concentration that prevented the color change of the medium and exhibited complete inhibition of microbial growth $[16,22]$. The MBC was determined by adding $50 \mu \mathrm{L}$ aliquots of the preparations which did not show any growth after incubation during MIC assays to $150 \mu \mathrm{L}$ of $\mathrm{MHB}$. These preparations were further incubated at $37^{\circ} \mathrm{C}$ for $48 \mathrm{~h}$. The $\mathrm{MBC}$ was regarded as the lowest concentration of a sample, which did not induce a color change after addition of INT as mentioned above [16, 22].

2.6. Antibiotic-Activity Modulation Assays. To evaluate the potentiating effect of the tested crude extracts, a preliminary assay was performed using the association of extracts at their various subinhibitory concentrations with antibiotics against one of a problematic bacterium, P. aeruginosa PA124. $\mathrm{MIC} / 2$ and $\mathrm{MIC} / 4$ of extracts were selected as the best subinhibitory concentrations $[16,23]$. Samples were tested at various subinhibitory concentrations (MIC/2, MIC/4, $\mathrm{MIC} / 8$, and MIC/16). Results allowed selecting MIC/2 and $\mathrm{MIC} / 4$ as subinhibitory concentrations for further experiments on selected Gram-negative bacteria. Briefly, after serial dilution of antibiotic, extract was added to each well at its subinhibitory concentration and the bacterial inoculation was done; the MIC was further determined. Antibiotics were tested in the concentration ranges of $2-256 \mu \mathrm{g} / \mathrm{mL}$ or $0.5-64 \mu \mathrm{g} / \mathrm{mL}$ when it was necessary. Rows receiving antibiotic dilutions without extracts were used for the determination of the MICs of the antibiotics. The modulation factor was defined as the ratio of the MIC of antibiotic alone versus that of antibiotic in the presence of extract. Modulation factor $\geq 2$ was set as the cut-off for biological significance of antibiotic-resistance modulating effects [24].

\section{Results}

3.1. Phytochemical Composition of Plant Extracts. The results of the qualitative phytochemical screening showed that each plant extract contains at least one of the secondary 


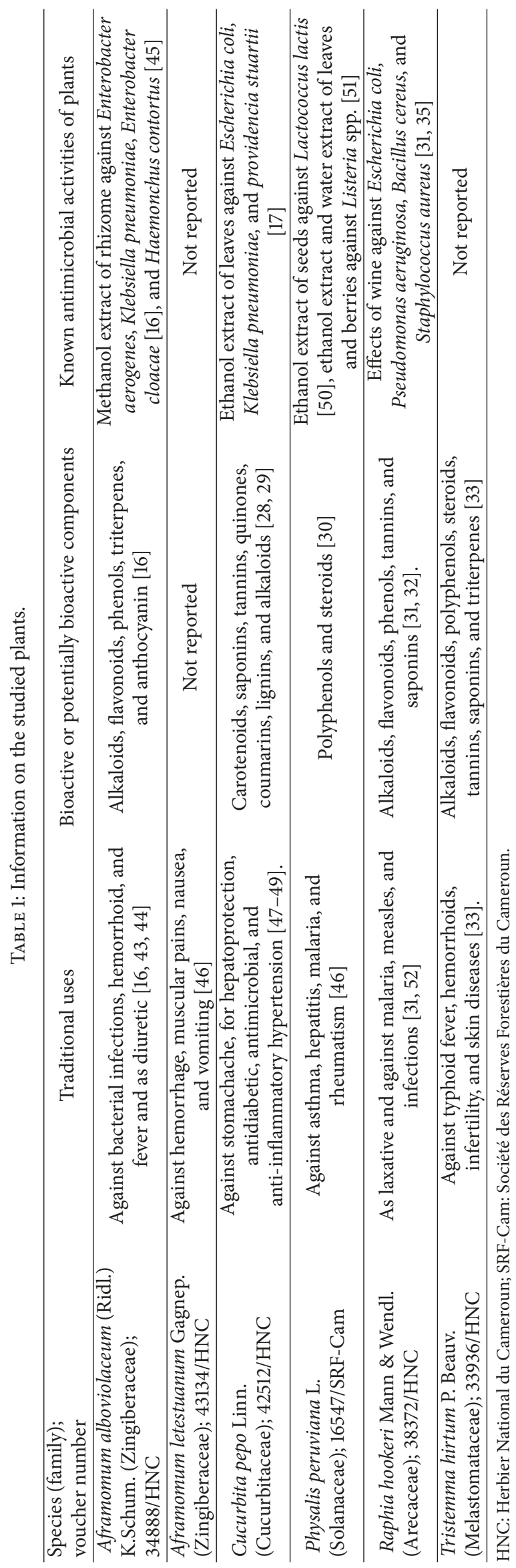


TABLE 2: Extraction yields and phytochemical composition of the plant extracts.

\begin{tabular}{|c|c|c|c|c|c|c|c|c|c|c|}
\hline Plant extracts & Part used & Yields (\%) & alk & pol & flav & anthr & $\tan$ & tri & ster & sap \\
\hline \multirow{2}{*}{ Aframomum alboviolaceum } & Stem & 3.1 & + & + & + & + & + & + & + & - \\
\hline & Leaves & 8.7 & + & + & + & + & - & + & + & + \\
\hline Aframomum letestuanum & Leaves & 3.7 & + & + & + & - & + & + & + & + \\
\hline Cucurbita pepo & Pericarps & 9.1 & + & + & + & - & + & + & + & - \\
\hline Physalis peruviana & Stem & 4.05 & + & + & - & + & + & + & + & - \\
\hline Raphia hookeri & Pericarps & 5.2 & + & + & + & + & + & - & + & + \\
\hline Tristemma hirtum & Leaves & 10.4 & - & + & + & + & - & + & + & + \\
\hline
\end{tabular}

-: absent; +: present. Yield was calculated as the ratio of the mass of the obtained methanol extract/mass of the plant powder. alk: alkaloids; anthr: anthraquinones; flav: flavonoids; pol: polyphenols; sap: saponins; ster: steroids; tan: tannins; tri: triterpenes.

metabolites classes such as alkaloids, anthraquinones, flavonoids, phenols, saponins, tannins, steroids, and triterpenes. Polyphenols and steroids were present in all the extracts (Table 2).

3.2. Antibacterial Activity. Plant extracts were tested for their antibacterial activities on a panel of 20 Gram-negative bacteria. Results summarized in Table 3 showed that all extracts were active on at least one bacterial strain with MIC values ranging from 512 to $2048 \mu \mathrm{g} / \mathrm{mL}$. The extracts of Raphia hookeri pericarps (RHP), Tristemma hirtum leaves (THL), and Cucurbita pepo pericarps (CPP) were more active. They presented the lowest MIC value $(512 \mu \mathrm{g} / \mathrm{mL})$ against $E$. coli ATCC8739 (RHP), E. coli AG100 (THL), E. coli MC4100 (CCP and THL), P. stuartii PS299645 (RHP, CCP, and THL), $E$ aerogenes EA294 (RHP), and $P$. aeruginosa PA01 (RHP). In general, $\mathrm{MBC}$ values recorded for the extracts were more than $2048 \mu \mathrm{g} / \mathrm{mL}$.

3.3. Antibiotic-Resistance Modulation Activity of Extracts. The antibacterial activities of six commonly used antibiotics were evaluated in absence/presence of the different plant extracts. The results of the prescreening of the tested plant extracts for their antibiotic-resistance modulating effects against $P$. aeruginosa PA124 (Table 4) allowed us to select 4 plant extracts (leaves extracts of T. hirtum, Aframomum letestuanum, Aframomum alboviolaceum, and the pericarps extract of Raphia hookeri) for the study of their modulating effects against selected MDR bacteria, these at the concentrations equivalent to the half and quarter of their MIC values. It was observed that some extracts selectively improved the antibacterial activities of the tested antibiotics by decreasing their MIC values at about 2 to 64 times (Tables 5-8). The most important effects were observed with leaves extracts of Tristemma hirtum which significantly improved the antibacterial activities of all the tested antibiotics against 70\% (7/10) to $100 \%(10 / 10)$ of the MDR bacteria used for the study. The activities of CHL, KAN, and CIP were mostly improved (2 to 128 times) as well as $\mathrm{MIC} / 2$ compared to at $\mathrm{MIC} / 4$ values (Table 8). The pericarps extract of Raphia hookeri also showed significant antibiotic-potentiating activities in more than $70 \%(7 / 10)$ of the tested MDR bacteria. Its modulating effect was more important when it was associated with CHL, KAN, STP, ERY, and TET, mainly at the half of its MIC values (Table 7). The antibiotic-modulating effects of the other extracts (Aframomum letestuanum and Aframomum alboviolaceum) were not significant. They were observed on less than $50 \%$ of the tested MDR bacteria (Tables 5 and 6 ).

\section{Discussion}

4.1. Phytochemical Composition of Extracts. Plant secondary metabolites including flavonoids, phenols, terpenoids, steroids, saponins, and tannins are known for their antimicrobial activities [25-27]. In this study, phytochemical screening of the tested extracts indicated the presence of at least one of these metabolites in each extract (Table 2). Their presence in the studied extracts could therefore explain the observed activities. Also, terpenoids and phenolics were previously reported in Aframomum alboviolaceum [16], Cucurbita pepo $[28,29]$, Physalis peruviana [30], Raphia hookeri $[31,32]$, and Tristemma hirtum [33]. Their presence in the tested plant extract is in conformity with the previous phytochemical investigations.

4.2. Antibacterial Potential of Extracts. Based on the cut-off values indicating the antibacterial activity of plant extracts proposed by Kuete [34], many of the tested extracts, especially those from Tristemma hirtum leaves (THL), Raphia hookeri pericarps (RHP), and Cucurbita pepo pericarps (CPP) had weak $(>512 \mu \mathrm{g} / \mathrm{mL})$ to no activity $(\mathrm{MIC}>2048 \mu \mathrm{g} / \mathrm{mL})$ against the tested bacteria (Table 2). Previous studies have already demonstrated their in vitro antibacterial activities against many pathogenic microorganisms including bacteria. Oboh et al. [35] demonstrated the antibacterial properties of Raphia hookeri syrup against E. coli, P. aeruginosa, and $S$. aureus. According to these authors, the observed activity may be attributed to the presence of phenolic compounds including tannins, saponins, and flavonoids, which were also highlighted in the methanol extract used in this work. With regard to Tristemma hirtum, the studies carried out by Noumedem [36] previously demonstrated its antibacterial activity against selected sensitive bacterial strains including E. coli, $P$. aeruginosa, S. flexneri, K. pneumonia, S. typhi, S. paratyphi, and E. faecalis. Ahoua et al. [37] showed that a plant belonging to the same genus, Tristemma coronatum, presented inhibitory power against various bacterial strains. This is in accordance with the results obtained in this study. Noumedem et al. [17] showed that the methanol leaves extract of Cucurbita pepo has significant antibacterial activity against 


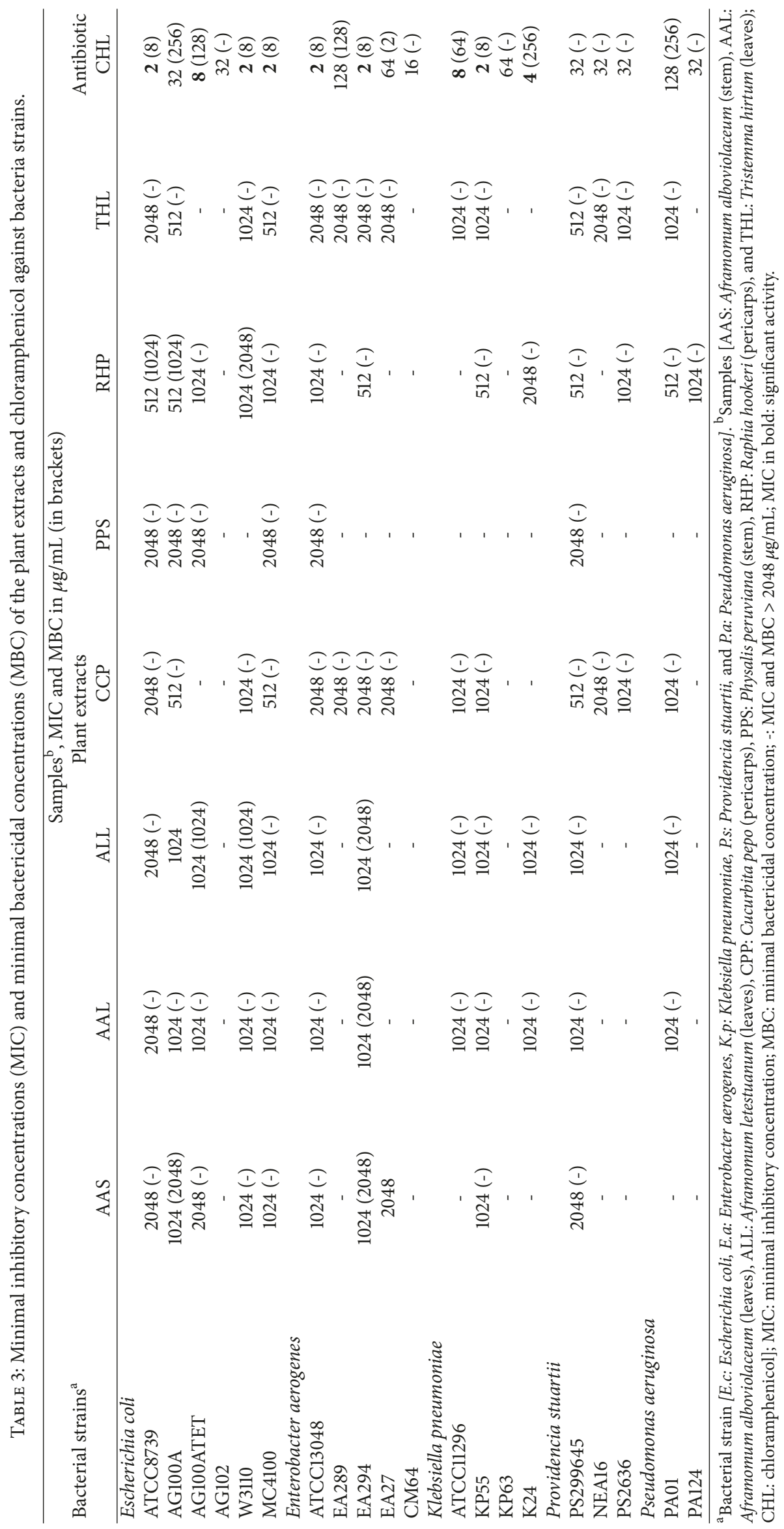


TABLE 4: Preliminary evaluation of antibiotic-resistance modulatory activity of selected extracts at subinhibitory concentrations against Pseudomonas aeruginosa PA124.

\begin{tabular}{|c|c|c|c|c|c|c|c|}
\hline \multirow[t]{2}{*}{ Plant extracts } & \multirow{2}{*}{$\begin{array}{l}\text { Extract } \\
\text { concentration }\end{array}$} & \multicolumn{6}{|c|}{$\begin{array}{c}\text { MIC of antibiotic }(\mu \mathrm{g} / \mathrm{mL}) \text { alone and in combination with extracts }{ }^{\mathrm{a}} \text { and fold increase of activity (in } \\
\text { brackets) }\end{array}$} \\
\hline & & $\mathrm{CHL}$ & KAN & CEF & CIP & TET & ERY \\
\hline & 0 & 128 & 128 & 128 & 64 & 16 & 128 \\
\hline \multirow{4}{*}{ AAL } & $\mathrm{MIC} / 2$ & $32(4)$ & $64(2)$ & $128(1)$ & $64(1)$ & $8(2)$ & $128(1)$ \\
\hline & $\mathrm{MIC} / 4$ & $64(2)$ & $64(2)$ & $128(1)$ & $64(1)$ & $8(2)$ & $256(0.5)$ \\
\hline & $\mathrm{MIC} / 8$ & $64(2)$ & $128(1)$ & $128(1)$ & $64(1)$ & $16(1)$ & $256(0.5)$ \\
\hline & $\mathrm{MIC} / 16$ & $128(1)$ & $128(1)$ & $128(1)$ & $64(1)$ & $16(1)$ & $256(0.5)$ \\
\hline \multirow{4}{*}{ ALL } & $\mathrm{MIC} / 2$ & $128(1)$ & $64(2)$ & $128(1)$ & $64(1)$ & $8(2)$ & $256(0.5)$ \\
\hline & $\mathrm{MIC} / 4$ & $128(1)$ & $64(2)$ & $128(1)$ & $64(1)$ & $8(2)$ & $256(0.5)$ \\
\hline & MIC/8 & $128(1)$ & $128(1)$ & $128(1)$ & $64(1)$ & $16(1)$ & $256(0.5)$ \\
\hline & $\mathrm{MIC} / 16$ & $128(1)$ & $128(1)$ & $128(1)$ & $64(1)$ & $16(1)$ & $256(0.5)$ \\
\hline \multirow{4}{*}{ RHP } & $\mathrm{MIC} / 2$ & $32(4)$ & $32(4)$ & $64(2)$ & $32(2)$ & $8(2)$ & $64(2)$ \\
\hline & $\mathrm{MIC} / 4$ & $64(2)$ & $64(2)$ & $128(1)$ & $64(1)$ & $16(1)$ & $128(1)$ \\
\hline & MIC/8 & $128(1)$ & $64(2)$ & $256(0.5)$ & $64(1)$ & $16(1)$ & $128(1)$ \\
\hline & $\mathrm{MIC} / 16$ & $128(1)$ & $64(2)$ & $256(0.5)$ & $64(1)$ & $16(1)$ & $128(1)$ \\
\hline \multirow{4}{*}{ THL } & $\mathrm{MIC} / 2$ & $8(16)$ & $64(2)$ & $128(1)$ & $32(2)$ & $8(2)$ & $128(1)$ \\
\hline & $\mathrm{MIC} / 4$ & $8(16)$ & $64(2)$ & $256(0.5)$ & $32(2)$ & $8(2)$ & $256(0.5)$ \\
\hline & $\mathrm{MIC} / 8$ & $32(4)$ & $64(2)$ & $256(0.5)$ & $32(2)$ & $8(2)$ & $256(0.5)$ \\
\hline & MIC/16 & $32(4)$ & $64(2)$ & $256(0.5)$ & $32(2)$ & $8(2)$ & $256(0.5)$ \\
\hline
\end{tabular}

a Samples [AAL: Aframomum alboviolaceum (leaves), ALL: Aframomum letestuanum (leaves), RHP: Raphia hookeri (pericarps), THL: Tristemma hirtum (leaves), CHL: chloramphenicol, CEF: ceftriaxone, CIP: ciprofloxacin, ERY: erythromycin, KAN: kanamycin, STR: streptomycin, and TET: tetracycline]; in brackets: modulating factor; MIC: minimal inhibitory concentration. Values in bold represent modulating factor $\geq 2$.

the bacterial strains used in this work. The difference of the activity may be due to the fact that different parts of the plants were used in the two studies. Even though the antibacterial activities of the tested plant extracts were in general moderate to low, if we consider the features of the bacteria used in this study (Table S1, supplementary materials) and the fact that the plants used are edible plants, some like the extract of leaves of Tristemma hirtum and extracts of pericarps of Raphia hookeri and Cucurbita pepo could be used to fight bacterial infections.

4.3. Antibiotic-Modulation Effects of Extracts. Infections due to MDR Gram-negative bacteria are particularly concerning as such bacteria are demonstrating resistance to practically all current licensed therapies [2, 4, 38]. Numerous ranges of novel approaches are under investigation as potential alternative treatments. Among them, the use of plant-derived substances to target different antibiotic resistance systems in the bacteria is considered as one of the best strategies [10, 39, 40]. In this study, nine methanol plant extracts were tested for their ability to modulate the activity of some common antibiotics. As the main results, it was observed that the activities of all tested antibiotics, especially those of CHL, KAN, CIP, and TET, were improved 2 to 128 times against more than $70 \%$ of the tested MDR bacteria in the presence of the extracts of leaves of Tristemma hirtum and pericarps of Raphia hookeri (Tables 7 and 8). According to some reviews, plant-derived substances can act in synergy with antibiotics by inhibiting bacterial efflux pumps, allowing an increase of the intracellular concentrations of the antibiotics [7, 41]. Thus, because the bacteria used in this work express efflux pumps as the main resistance mechanism (Table S1, supplementary materials), the results obtained herein suggest that the aforesaid extracts could contain efflux pumps inhibitors [42]. According to Okusa and Duez [39], such effects may be due to the presence of alkaloids, flavonoids, terpenoids, and tannins in those extracts. Additionally, the tested extracts presented some antagonist actions with the antibiotics. This could be due to negative interactions between the antibiotics and the compounds present in the tested extracts. Finally, the most active extracts, extracts of leaves of Tristemma hirtum and pericarps of Raphia hookeri, could be used to stimulate the renewed use of antibiotics with reduced effectiveness due to resistance.

\section{Conclusion}

With respect to the main findings of this work, the extracts of leaves of Tristemma hirtum and pericarps of Raffia hookeri appear as sources of substances that can be promising potentiating agents of antibiotics, even though they have moderate direct antibacterial action against the tested MDR bacteria. 


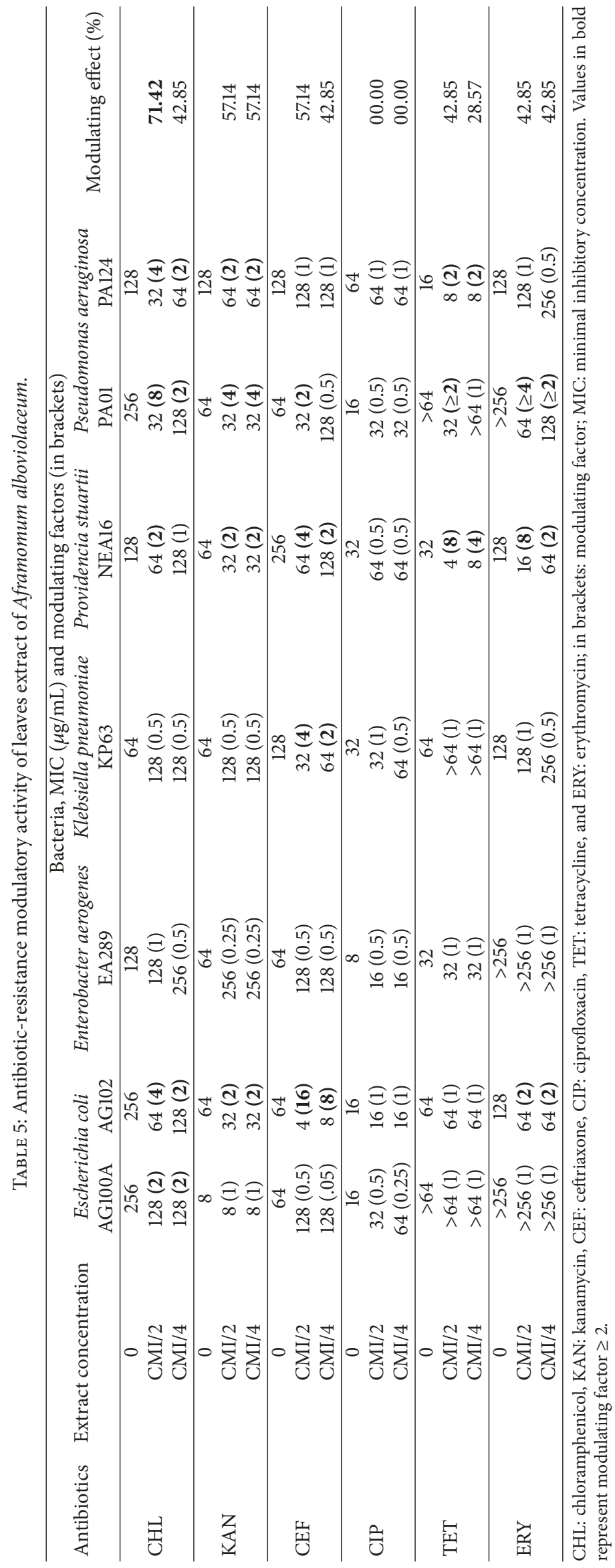




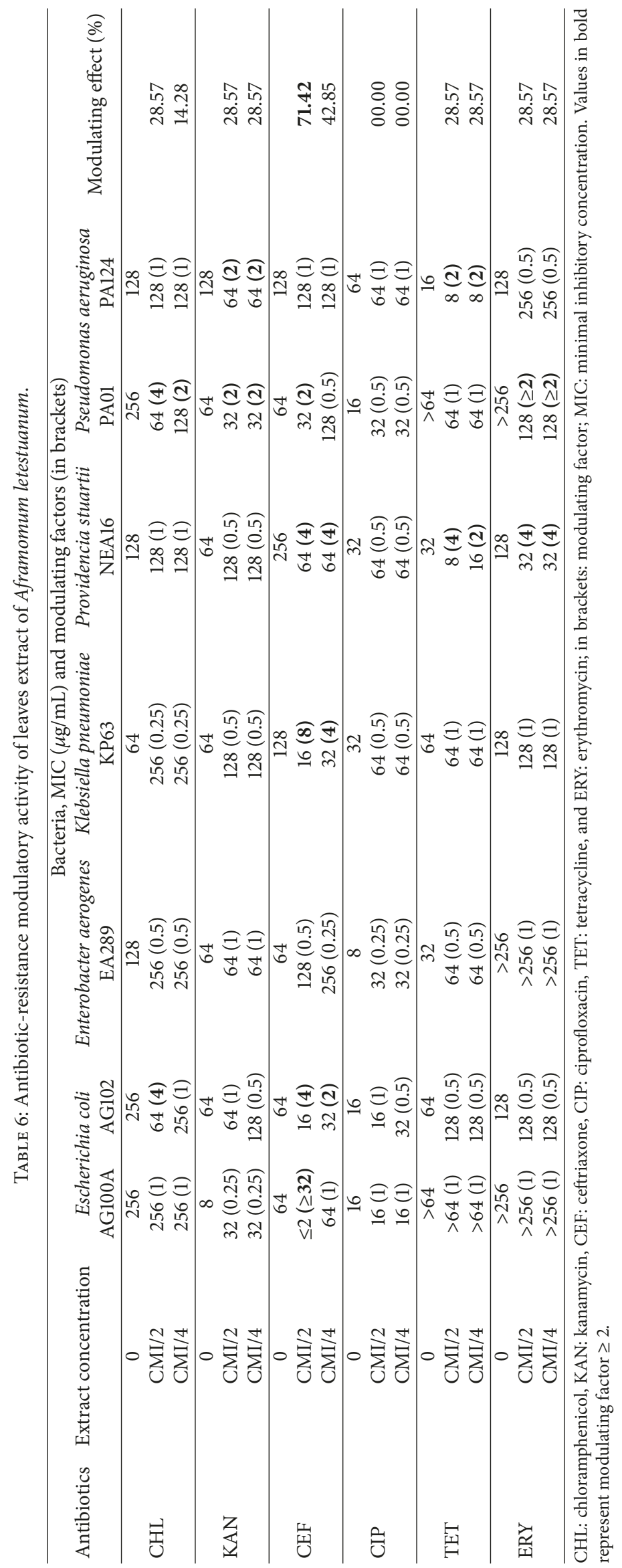




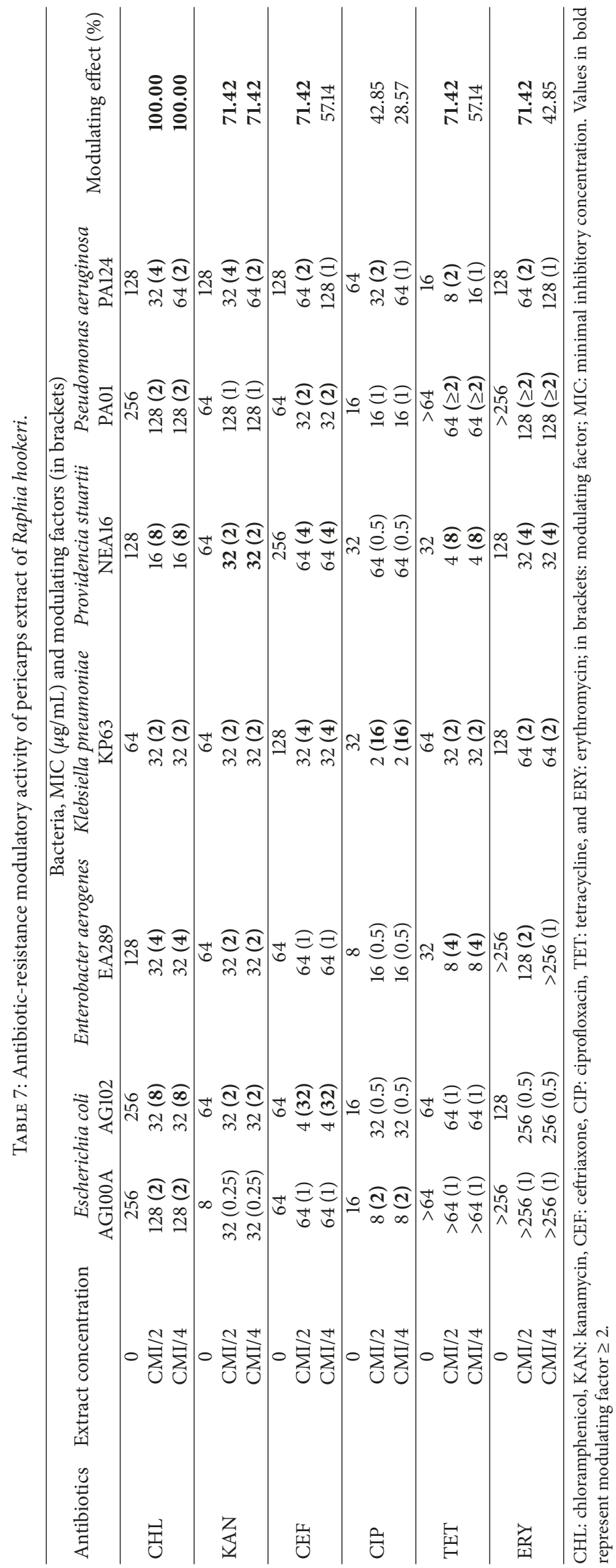




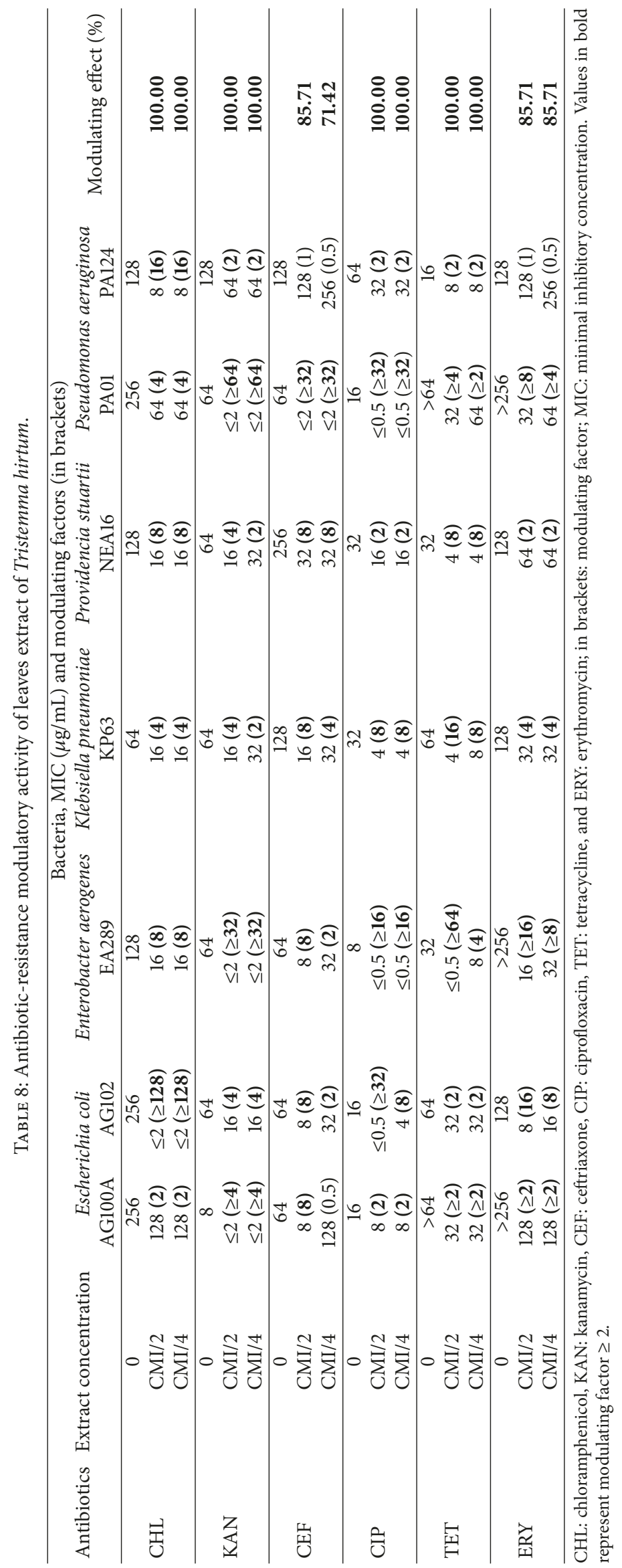




\section{Conflicts of Interest}

The authors declare that they have no conflicts of interest.

\section{Authors' Contributions}

Gaëlle S. Nguenang, Hermione T. Manekeng, Paul Nayim, and Brice E. N. Wamba carried out the study; Armelle T. Mbaveng and Victor Kuete designed the experiments; Aimé G. Fankam, Armelle T. Mbaveng, and Victor Kuete wrote the manuscript; Armelle T. Mbaveng and Victor Kuete supervised the work and provided the bacterial strains; all authors read and approved the final manuscript.

\section{Acknowledgments}

The authors are thankful to the Cameroon National Herbarium for identification of plants.

\section{Supplementary Materials}

Table S1: Gram-negative bacteria used and their features and further details on the antibiotic-resistance profiles of tested Gram-negative bacteria. (Supplementary Materials)

\section{References}

[1] M. Bassetti, F. Ginocchio, M. Mikulska, L. Taramasso, and D. R. Giacobbe, "Will new antimicrobials overcome resistance among Gram-negatives?" Expert Review of Anti-infective Therapy, vol. 9, no. 10, pp. 909-922, 2011.

[2] Z.-Q. Xu, M. T. Flavin, and J. Flavin, "Combating multidrugresistant Gram-negative bacterial infections," Expert Opinion on Investigational Drugs, vol. 23, no. 2, pp. 163-182, 2014.

[3] M. Bassetti, D. Pecori, and M. Peghin, "Multidrug-resistant Gram-negative bacteria-resistant infections: Epidemiology, clinical issues and therapeutic options," Italian Journal of Medicine, vol. 10, no. 4, pp. 364-375, 2016.

[4] R. Huwaitat, A. P. McCloskey, B. F. Gilmore, and G. Laverty, "Potential strategies for the eradication of multidrug-resistant Gram-negative bacterial infections," Future Microbiology, vol. 11, no. 7, pp. 955-972, 2016.

[5] B. J. Kamicker, M. T. Sweeney, F. Kaczmarek et al., "Bacteria efflux pomp inhibitors," Methods in molecular medicine, vol. 142, pp. 187-204, 2008.

[6] M. D. Zilberberg, A. F. Shorr, S. T. Micek, C. Vazquez-Guillamet, and M. H. Kollef, "Multi-drug resistance, inappropriate initial antibiotic therapy and mortality in Gram-negative severe sepsis and septic shock: a retrospective cohort study," Critical Care, vol. 18, no. 6, p. 596, 2014.

[7] M. Stavri, L. J. V. Piddock, and S. Gibbons, "Bacterial efflux pump inhibitors from natural sources," Journal of Antimicrobial Chemotherapy, vol. 59, no. 6, pp. 1247-1260, 2007.

[8] J. L. Liscio, M. V. Mahoney, and E. B. Hirsch, "Ceftolozane/ tazobactam and ceftazidime/avibactam: Two novel $\beta$-lactam $/ \beta$ lactamase inhibitor combination agents for the treatment of resistant Gram-negative bacterial infections," International Journal of Antimicrobial Agents, vol. 46, no. 3, pp. 266-271, 2015.

[9] G. G. Zhanel, P. Chung, H. Adam et al., "Ceftolozane/tazobactam: A novel cephalosporin/ $\beta$-lactamase inhibitor combination with activity against multidrug-resistant gram-negative bacilli," Drugs, vol. 74, no. 1, pp. 31-51, 2014.
[10] T. Sibanda and A. I. Okoh, "The challenges of overcoming antibiotic resistance: plant extracts as potential sources of antimicrobial and resistance modifying agents," African Journal of Biotechnology, vol. 6, no. 25, pp. 2886-2896, 2007.

[11] O. A. Aiyegoro and A. I. Okoh, "Use of bioactive plant products in combination with standard antibiotics: implications in antimicrobial chemotherapy," Journal of Medicinal Plants Research, vol. 3, no. 13, pp. 1147-1152, 2009.

[12] M. Saleem, M. Nazir, M. S. Ali et al., "Antimicrobial natural products: an update on future antibiotic drug candidates," Natural Product Reports, vol. 27, no. 2, pp. 238-254, 2010.

[13] A. G. Fankam, V. Kuete, I. K. Voukeng, J. R. Kuiate, and J.-M. Pages, "Antibacterial activities of selected Cameroonian spices and their synergistic effects with antibiotics against multidrugresistant phenotypes," BMC Complementary and Alternative Medicine, vol. 11, article no. 104, 2011.

[14] S. T. Lacmata, V. Kuete, J. P. Dzoyem et al., "Antibacterial activities of selected cameroonian plants and their synergistic effects with antibiotics against bacteria expressing MDR phenotypes," Evidence-Based Complementary and Alternative Medicine, vol. 2012, Article ID 623723, 11 pages, 2012.

[15] I. K. Voukeng, V. Kuete, J. P. Dzoyem et al., "Antibacterial and antibiotic-potentiation activities of the methanol extract of some cameroonian spices against Gram-negative multi-drug resistant phenotypes," BMC Research Notes, vol. 5, article no. 299, 2012.

[16] D. E. Djeussi, J. A. K. Noumedem, J. A. Seukep et al., "Antibacterial activities of selected edible plants extracts against multidrug-resistant Gram-negative bacteria," BMC Complementary and Alternative Medicine, vol. 13, article no. 164, 2013.

[17] J. A. K. Noumedem, M. Mihasan, S. T. Lacmata, M. Stefan, J. R. Kuiate, and V. Kuete, "Antibacterial activities of the methanol extracts of ten Cameroonian vegetables against Gram-negative multidrug-resistant bacteria," BMC Complementary and Alternative Medicine, vol. 13, article no. 26, 2013.

[18] J. K. Dzotam and V. Kuete, "Antibacterial and AntibioticModifying Activity of Methanol Extracts from Six Cameroonian Food Plants against Multidrug-Resistant Enteric Bacteria," BioMed Research International, vol. 2017, Article ID 1583510, 2017.

[19] J. B. Harbone, Phytochemical Methods: A Guide to Modern Techniques of Plant Analysis, Chapman and Hall Ltd, London, UK, 1973.

[20] V. Kuete, Medicinal Plant Research in Africa in: Pharmacology and Chemistry, Elsevier, Oxford, UK, 1st edition, 2013.

[21] J. N. Eloff, "A sensitive and quick microplate method to determine the minimal inhibitory concentration of plant extracts for bacteria," Planta Medica, vol. 64, no. 8, pp. 711-713, 1998.

[22] V. Kuete, G. F. Wabo, B. Ngameni et al., "Antimicrobial activity of the methanolic extract, fractions and compounds from the stem bark of Irvingia gabonensis (Ixonanthaceae)," Journal of Ethnopharmacology, vol. 114, no. 1, pp. 54-60, 2007.

[23] A. G. Fankam, J.-R. Kuiate, and V. Kuete, "Antibacterial and antibiotic resistance modulatory activities of leaves and bark extracts of Recinodindron heudelotii (Euphorbiaceae) against multidrug-resistant Gram-negative bacteria," BMC Complementary and Alternative Medicine, vol. 17, no. 1, article no. 168, 2017.

[24] J. Kovač, N. Gavarić, F. Bucar, and S. S. Možina, "Antimicrobial and resistance modulatory activity of alpinia katsumadai seed phenolic extract, essential oil and post-distillation extract," ood Technology and Biotechnology, vol. 52, no. 2, pp. 248-254, 2014. 
[25] M. M. Cowan, "Plant products as antimicrobial agents," Clinical Microbiology Reviews, vol. 12, no. 4, pp. 564-582, 1999.

[26] J. L. Ríos and M. C. Recio, "Medicinal plants and antimicrobial activity," Journal of Ethnopharmacology, vol. 100, no. 1-2, pp. 8084, 2005.

[27] K. L. Compean and R. A. Ynalvez, "Antimicrobial activity of plant secondary metabolites: A review," Research Journal of Medicinal Plant, vol. 8, no. 5, pp. 204-213, 2014.

[28] B. -. CARBIN, B. LARSSON, and O. LINDAHL, "Treatment of Benign Prostatic Hyperplasia with Phytosterols," British Journal of Urology, vol. 66, no. 6, pp. 639-641, 1990.

[29] T. Karpagam, B. Varalakshmi, J. S. Bai, and S. Gomathi, "Effect of different doses of Cucurbita pepo linn extract as an antiInflammatory and analgesic nutraceautical agent on inflamed rats," International journal of periodontics \& restorative dentistry, vol. 3, no. 3, pp. 184-192, 2011.

[30] M. F. Ramadan and J.-T. Morsel, "Oil goldenberry (Physalis peruviana L.)," Journal of Agricultural and Food Chemistry, vol. 51, no. 4, pp. 969-974, 2003.

[31] C. O. Ibegbulem, C. S. Alisi, P. Nwankpa, B. A. Amadi, M. A. Agiang, and V. S. Ekam, "Medicinal values of Elaeis guineensisand Raphia hookeriwines," Journal of Research in Biology, vol. 2, no. 6, pp. 589-595, 2012.

[32] M. N. Ogbuagu, "Vitamins, phytochemicals and toxic elements in the pulp and seed of raphia palm fruit (Raphia hookeri)," Fruits, vol. 63, no. 5, pp. 297-302, 2008.

[33] M. R. C. Dongmo, Evaluation of antidermatophytic activity of methanol extracts and fractions of Acalypha manniana (Euphorbiaceae) and Tristemma hirtum (Melastomataceae) [M.S. thesis], Department of Biochemistry, University of Dschang, Dschang, Cameroon, 2009.

[34] V. Kuete, "Potential of Cameroonian plants and derived products against microbial infections: A review," Planta Medica, vol. 76, no. 14, pp. 1479-1491, 2010.

[35] O. F. Oboh, L. Iyare, M. Idemudia, and S. Enabulele, "Physicochemical and nutritional characteristics, and antimicrobial activity of oil palm syrup, raffia palm syrup and honey," IOSR Journal of Pharmacy and Biological Sciences, vol. 11, no. 1, pp. 73-78, 2016.

[36] J. A. K. Noumedem, Antimicrobial, antioxidant and ant-diarrhea properties of Acalypha manniana and Tristemma hirtum [M.s. thesis], Department of Biochemistry, University of Dschang, Dschang, Cameroon, 2009.

[37] A. R. C. Ahoua, A. G. Konan, B. Bonfoh, and M. W. Koné, "Antimicrobial potential of 27 plants consumed by chimpanzees (Pan troglodytes verus Blumenbach) in Ivory Coast," BMC Complementary and Alternative Medicine, vol. 15, no. 1, article no. 383, 2015.

[38] M. T. Mascellino, M. D. Angelis, and A. Oliva, "Multi-drug resistant gram-negative bacteria: antibiotic-resistance and new treatment strategies," Diagnostic Pathology: Open Access, vol. 2, no. 2, 4 pages, 2017.

[39] P. N. Okusa and P. Duez, "Chapitre 13: Medicinal plants: a tool to overcome antibiotic resistance?" in Medicinal Plants: Classification, Biosynthesis and Pharmacology, A. Varela and J. Ibañez, Eds., pp. 315-330, Nova Science Publishers, Inc, New York, NY, USA, 2009.

[40] E. F. F. Matias, K. K. A. Santos, T. S. Almeida, J. G. M. Costa, and H. D. M. Coutinho, "Enhancement of antibiotic activity by Cordia verbenacea DC, Latin American Journal of Pharmacy, vol. 29, no. 6, pp. 1049-1052, 2010.
[41] G. Tegos, F. R. Stermitz, O. Lomovskaya, and K. Lewis, "Multidrug pump inhibitors uncover remarkable activity of plant antimicrobials," Antimicrobial Agents and Chemotherapy, vol. 46, no. 10, pp. 3133-3141, 2002.

[42] L. C. Braga, A. A. M. Leite, K. G. S. Xavier et al., "Synergic interaction between pomegranate extract and antibiotics against Staphylococcus aureus," Canadian Journal of Microbiology, vol. 51, no. 7, pp. 541-547, 2005.

[43] P. M. Abreu and R. G. Noronha, "Volatile constituents of the rhizomes of Aframomum alboviolaceum (Ridley) K. Schum. from Guinea-Bissan," Flavour and Fragrance Journal, vol. 12, no. 2, pp. 79-83, 1997.

[44] G. B. Ilumbe, P. Van Damme, F. L. Lukoki, V. Joiris, M. Visser, and J. Lejoly, "Contribution à létude des plantes médicinales dans le traitement des hémorroides par les pygmées Twa et leur voisin Oto de Bikoro, en RDC," Congo Sciences, vol. 2, no. 1, pp. 46-54, 2014.

[45] W. M. Koné, K. K. Atindehou, T. Dossahoua, and B. Betschart, "Anthelmintic activity of medicinal plants used in northern Côte d'Ivoire against intestinal helminthiasis," Pharmaceutical Biology, vol. 43, no. 1, pp. 72-78, 2005.

[46] D. M. Yemele, B. P. Telefo, S. C. Goka et al., "In vtro cytotoxicity studies of sixteen plants used for pregnant women's health conditions in menoua division-West Cameroon," International Journal of Phytomedicine, vol. 7, no. 2, pp. 235-239, 2015.

[47] G. K. A. Adepoju and A. A. Adebanjo, "Effect of consumption of Cucurbita pepo seeds on haematological and biochemical parameters," African Journal of Pharmacy and Pharmacology, vol. 5, no. 1, pp. 18-22, 2011.

[48] A. Jafarian, B. Zolfaghari, and M. Parnianifard, "The effects of methanolic, chloroform, and ethylacetate extracts of the cucurbita pepo L. On the delay type hypersensitivity and antibody production," Research in Pharmaceutical Sciences, vol. 7, no. 4, pp. 217-224, 2012.

[49] S. Sarkar and D. Guha, "Effect of ripe fruit pulp extract of Cucurbita pepo Linn. in aspirin induced gastric and duodenal ulcer in rats," Indian Journal of Experimental Biology (IJEB), vol. 46, no. 9, pp. 639-645, 2008.

[50] Ö. Çakir, M. Pekmez, E. Çepni, B. Candar, and K. Fidan, "Evaluation of biological activities of physalis peruviana ethanol extracts and expression of Bcl-2 genes in HeLa cells," Food Science and Technology, vol. 34, no. 2, pp. 422-430, 2014.

[51] M. B. Cueva, R. A. Tigre León, M. M. Angel Yanchaliquín, and I. F. Herminia Sanaguano Salguero, "Antibacterial Effects of Uvilla (Physalis peruviana L.) extracts against Listeria spp. Isolated from Meat in Ecuador," International Journal of Current Microbiology and Applied Sciences, vol. 6, no. 4, pp. 1146-1153, 2017.

[52] R. Irvine, Woody Plant of Ghana with Special Reference to Their Uses, Oxford University Press, Oxford, UK, 1961. 

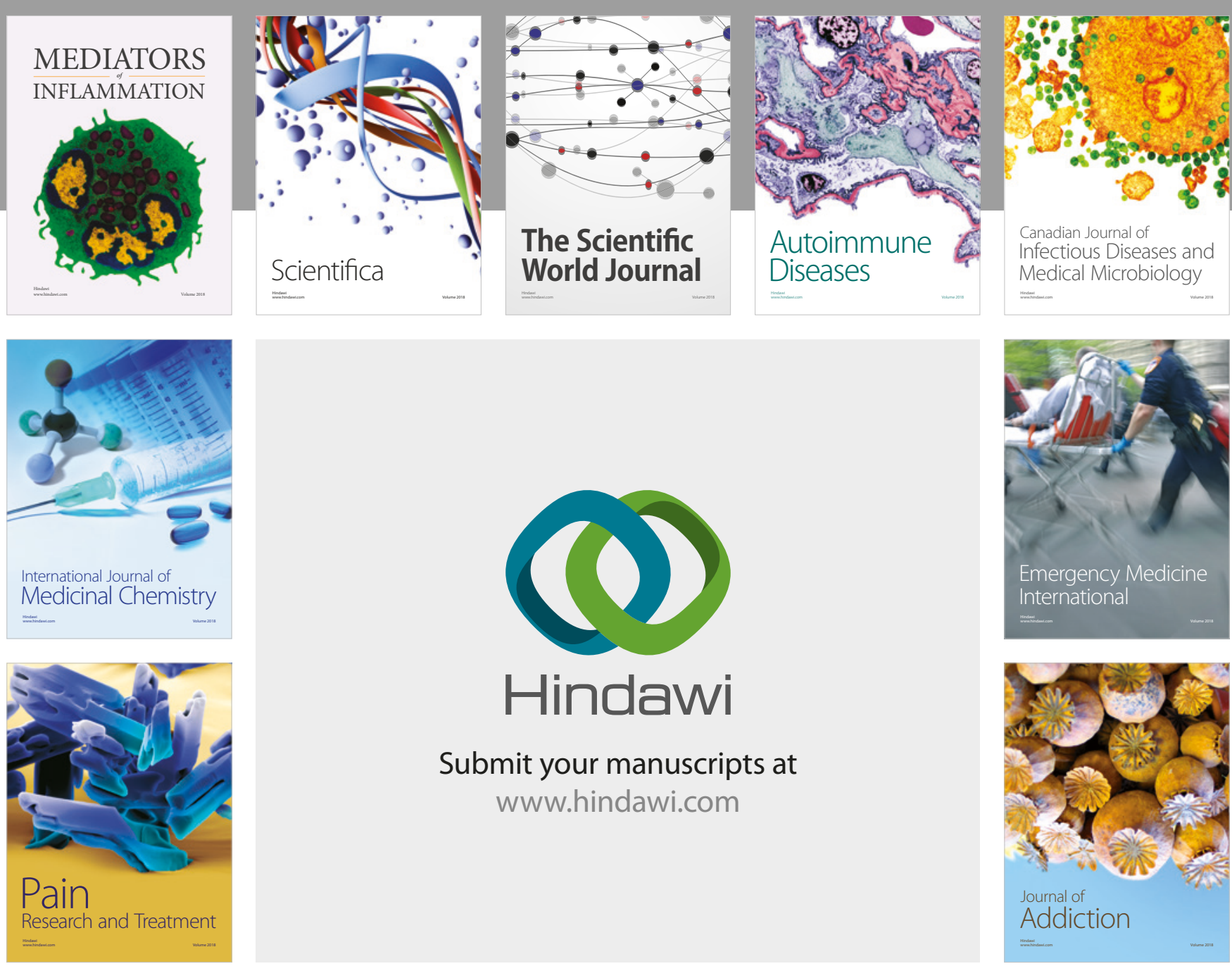

Canadian Journal of
Infectious Diseases and Medical Microbiology

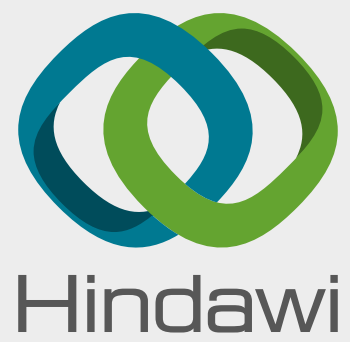

Submit your manuscripts at

www.hindawi.com
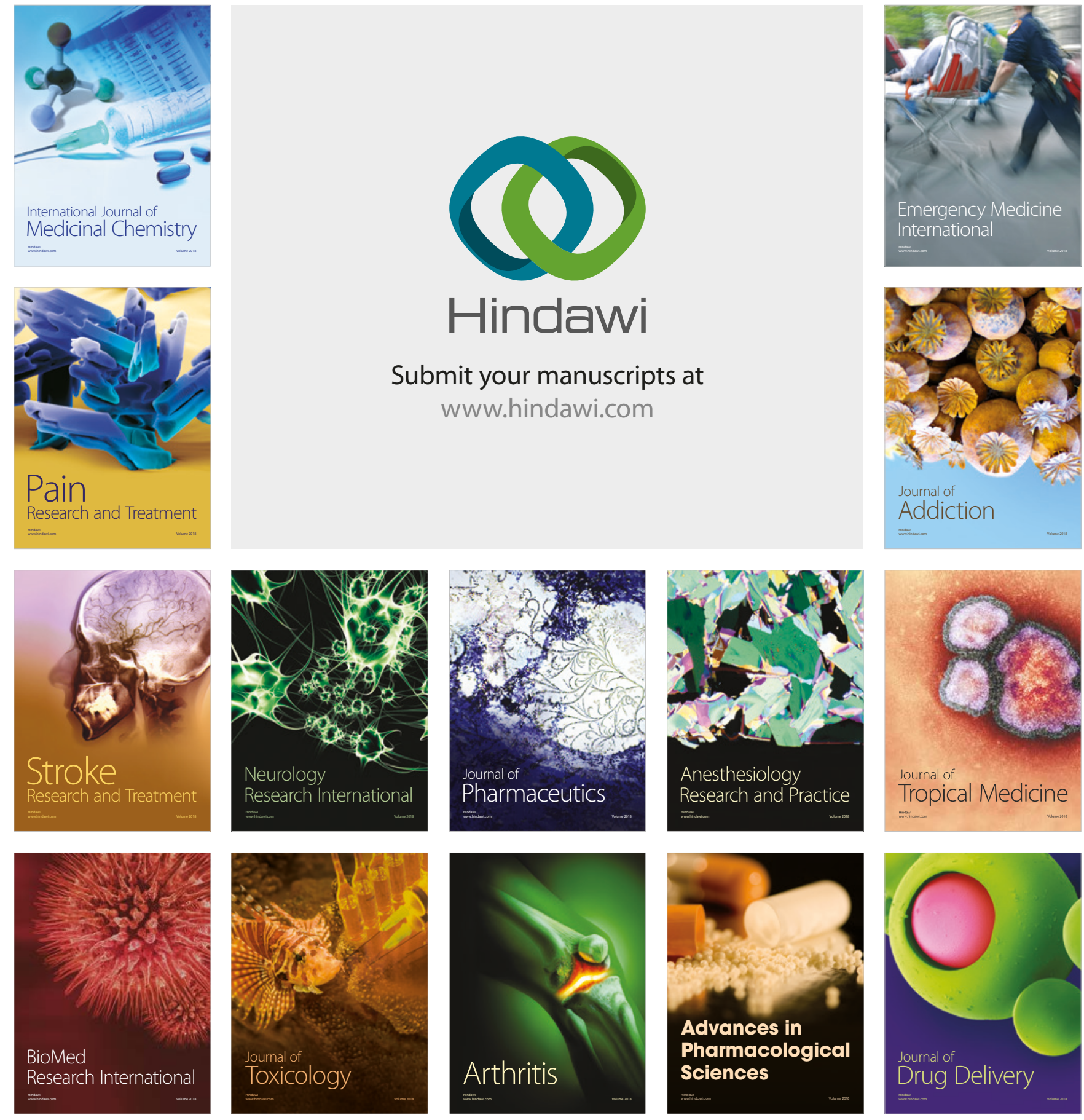